\title{
MEASURING EXPERIENCE ECONOMY AND VISITOR BEHAVIOR: EMPIRICAL STUDY OF SAWAHLUNTO CITY TOURISM DESTINATIONS
}

\author{
Yofina Mulyati1* and Dedi Fernanda2* \\ * *Dharma Andalas University, Economic and Bisnis Faculty \\ J1. Sawahan No. 103 A, Simpang Haru, Padang, Inodnesia \\ Email: yofina@unidha.ac.id
}

\begin{abstract}
Abstrak
Penelitian ini bertujuan melihat perilaku wisatawan dari segi (1) pengaruh educational experience terhadap emotion, (2) pengaruh entertainment experience terhadap emotion, (3) pengaruh escapism experience terhadap emotion, (4) pengaruh esthetics experience terhadap emotion, (5) pengaruh emotion terhadap kepuasan (satisfaction), (6) pengaruh emotion terhadap behavioral intentions, (7) pengaruh kepuasan (satisfaction) terhadap behavioral intentions. Objek penelitian adalah wisatawan yang berkunjung ke destinasi wisata Kota Sawahlunto tahun 2019 dengan jumlah sampel 246 orang wisatawan. Teknik pengambilan sampel menggunakan accidental sampling. Metode analisa datanya adalah Partial Least Square (PLS). Hasil penelitian menunjukkan bahwa education, escapism, dan esthetics secara parsial berpengaruh positif signifikan terhadap emotion, sedangkan entertainment tidak berpengaruh positif signifikan terhadap emotion, emotion berpengaruh positif signifikan terhadap satisfaction serta behavioral intentions. Kemudian satisfaction berpengaruh positif signifikan terhadap behavioral intentions.
\end{abstract}

\section{Kata Kunci : Experience Economy, Emotion, Satisfaction, Behavioral Intention}

\begin{abstract}
This study aims to look at tourist behavior in terms of (1) the effect of educational experience on emotion, (2) the effect of entertainment experience on emotion, (3) the effect of escapism experience on emotion, (4) the effect of esthetics experience on emotion, (5) the effect of emotion on satisfaction (satisfaction), the effect of emotion on behavioral intentions, (7) the effect of satisfaction on behavioral intentions. The object of research is tourists visiting Sawahlunto City tourist destinations in 2019 with a sample of 246 tourists. The sampling technique uses accidental sampling. The data analysis method is Partial Least Square (PLS). The results showed that education, escapism, and esthetics partially had a significant positive effect on emotion, while entertainment had no significant positive effect on emotion, emotion had a significant positive effect on satisfaction and behavioral intentions. Then satisfaction has a significant positive effect on behavioral intentions.
\end{abstract}

\section{Keyword: Experience Economy, Emotion, Satisfaction, Behavioral Intention}

\section{Pendahuluan}

Pertumbuhan ekonomi suatu negara salah satunya dapat didorong oleh sektor pariwisata. Hal ini dikarenakan wisatawan yang berkunjung ke sebuah destinasi wisata merupakan penikmat jasa dari industri pariwisata sehingga dapat dijadikan sumber devisa bagi daerah tujuan wisatanya. Selain itu daerah destinasi wisata tersebut juga dapat menciptakan peluang usaha bagi masyarakat untuk mendapatkan pendapatan baik dari segi penginapan, kuliner makanan, maupun pelayanan jasa lain yan dapat menunjang sebuah destinasi wisata. Salah satu Kota yang menggunakan pariwisata untuk konsep pengembangan ekonomi daerah di masa depan adalah Kota Sawahlunto. Dimana Kota Sawahlunto ini termasuk bagian dari provinsi Sumatera Barat. Selanjutnya untuk menegaskan pengembangan sektor pariwisata jadi prioritas yang utama pada pembangunan daerah Kota Sawahlunto dapat dilihat dari komitmen bersama seluruh stakeholder Kota 215 | Jurnal Akuntansi, Ekonomi dan Manajemen Bisnis | Vol. 7 No.2, December 2019, 215-228 | E-ISSN: 2548-9836 
melalui Peraturan Daerah Kota Sawahlunto Nomor 2 Tahun 2001 tentang Visi Kota yaitu "Sawahlunto tahun 2020 Menjadi Kota Wisata Tambang yang Berbudaya". Berdasarkan visi Kota Sawahlunto maka konsep pengembangan pariwisatanya adalah dengan memperlihatkan sisi menarik sejarah penambangan batubara. Namun dari sisi menarik tersebut tidak hanya akan memperlihatkan yang bersifat fisik seperti alat-alat tambang, lokasi tambang dan lorong-lorong panjang tambang bawah tanah yang telah ataupun belum ditinggalkan, melainkan juga akan menampilkan sejarah kemanusiaan dari kerasnya kehidupan tambang batu bara serta budaya masyarakatnya yang akrab dan unik sebagai hasil pembauran berbagai etnik yang pernah tinggal menjadi penduduk Kota. Selain objek wisata tambang, Kota Sawahlunto juga mempersiapkan dan menyediakan sarana pariwisata lainnya seperti hiburan dan rekreasi yang mengikuti perkembangan zaman.

Peneliti tertarik melakukan penelitian di Kota Sawahlunto karena Kota Sawahlunto dikenal sebagai Kota penghasil batubara sejak Willem Hendrik de Greve ahli geologi asal Belanda sekitar tahun 1867 menemukan kandungan batubara di aliran Sungai Batang Ombilin. Pendayagunaan dan produksi batubara pertama dimulai tahun 1892 sehingga Sawahlunto pun menjelma menjadi Kota tambang. Seiring berjalannya waktu, produksi batubara menurun sehingga menyebabkan berpindahnya sebagian pekerja tambang ke Kota lain dan Sawahlunto pun menjadi Kota mati. Namun sejak ditetapkannya visi baru untuk membangun daerah, yakni mewujudkan Kota Wisata Tambang yang Berbudaya, Sawahlunto pun berbenah diri dan berangsur pulih ketika sektor pariwisata mulai berkembang secara umum, meskipun didominasi wisata sejarah (kompas.com, 2019).

Namun selama ini wisata sejarah kurang menarik bagi wisatawan untuk dikunjungi terutama khususnya bagi wisatawan nusantara, baik untuk destinasi wisata Kota Sawahlunto ataupun pada destinasi wisata di Kota-Kota lainnya. Hal ini berbanding terbalik dengan wisatawan mancanegara yang menyukai tempat-tempat yang memiliki keunikan. Selain itu ini juga dibuktikan dengan masuknya Kota Sawahlunto dalam nominasi Situs Warisan Budaya Dunia UNESCO. Sawahlunto yang tadinya terkenal sebagai Kota batubara kini lebih dikenal sebagai Kota wisata (Tribuntravel.com, 2019). Hal ini yang membuat peneliti tertarik melakukan penelitian di Kota Sawahlunto

Berdasarkan kunjungan wisatawan tersebut maka perkembangan jumlah wisatawan yang berkunjung ke Kota Sawahlunto baik nusantara maupun mancanegara periode 2014 sampai 2018 adalah sebagai berikut :

TABEL 1

JUMLAH WiSNUS (WISATAWAN NUSANTARA) DAN
WiSMAN (WISATAWAN MANCANEGARA)

Ke Kota Sawahlunto Periode 2014-2018

\begin{tabular}{|c|r|c|c|}
\hline Tahun & WISNUS & WISMAN & Jumlah \\
\hline 2014 & 174.345 & 245 & 174.590 \\
\hline 2015 & 185.900 & 467 & 186.367 \\
\hline 2016 & 276.432 & 536 & 276.968 \\
\hline 2017 & 150.321 & 890 & 151.211 \\
\hline 2018 & 78.532 & 970 & 75.902 \\
\hline
\end{tabular}

Sumber: Disbubparpora Kota Sawahlunto, 2019

Dari data pada tabel 1 dapat dijelaskan meski wisatawan nusantara yang datang ke destinasi wisata Kota Sawahlunto lebih banyak dibandingkan wisatawan mancanegara, ternyata jumlah wisatawan nusantara tersebut mengalami penurunan periode tahun 2017 sampai 2018 sedangkan jumlah wisatawan mancanegara mengalami peningkatan dari tahun 2014 sampai 2018. Hal ini menunjukkan bahwa keputusan wisatawan nusantara untuk berkunjung ke destinasi wisata Sawahlunto cenderung lebih rendah bila dibandingkan dengan wisatawan mancanegara. Dimana penurunan jumlah wisatawan nusantara ini dapat menunjukkan bahwa kurangnya keinginan wisatawan untuk mengunjungi ulang destinasi wisata yang sama dan bersedia merekomendasikannya kepada yang lain disebabkan banyaknya daya tarik wisata baru yang bermunculan ditempat lain dengan inovasi produk wisata baru dan beragam. Selain itu hal ini disebabkan pengalaman ekonomi (experience economy) yang mereka rasakan dan perasaan emosi (emotion) serta kepuasan (satisfaction) yang mereka dapatkan mempengaruhi niat berperilaku (behavioral intension) wisatawan. Experience economy (pengalaman ekonomi) terbagi atas 4 dimensi yaitu education (pendidikan), entertainment (hiburan), escapism (pelarian), dan esthetic (estetika).

Berdasarkan survey awal Desember 2018 pada 30 orang wisatawan yang berkunjung ke destinasi wisata di Kota Sawahlunto, mereka mengutarakan penilaian terhadap pengalaman ekonomi (experience economy), sebagai berikut : Dari segi education (pendidikan) 24 orang (80\%) para wisatawan tidak setuju memutuskan destinasi wisata Kota Sawahlunto mampu membuat wisatawan belajar sesuatu yang baru dalam kunjungan ke objek wisata ini. Hal ini dikarenakan menurut wisatawan belum semua destinasi wisata bisa memberikan pendidikan (education) disebabkan keterbatasan kemampuan 
wisatawan untuk menyerap informasi yang dialami saat berinteraksi dengan produk wisata yang ditawarkan meskipun destinasi wisata tersebut menawarkan wisata edukasi, contoh di lahan bekas tambang ataupun pada destinasi wisata kebun buah kandi yang dapat dijadikan sarana edukasi untuk mengenalkan berbagai macam buah-buahan. Kemudian dari segi escapism (pelarian) 14 orang $(46,6 \%)$ para wisatawan tidak setuju memutuskan destinasi wisata Kota Sawahlunto mampu membuat wisatawan terbawa ke dalam suasana yang berbeda pada saat berkunjung ke objek wisata tersebut. Hal ini dikarenakan menurut wisatawan destinasi wisata yang ada belum sepenuhnya menghadirkan suasana yang berbeda dengan destinasi lainnya di luar Kota Sawahlunto, disebabkan meskipun menampilkan wisata sejarah dan wisata alam maupun wisata edukasi pada dasarnya secara garis besar Kota Sawahlunto menampilkan wisata yang sama dengan destinasi wisata lainnya hanya saja produk wisata yang berbeda dan dikemas dengan cara yang berbeda sehingga jadi terlihat sama bagi orang-orang yang sudah pernah menikmati wisata sejarah dan wisata alam maupun wisata edukasi di destinasi wisata lainnya.

Sementara dari segi esthetic (estetika) 22 orang $(73.3 \%)$ tidak setuju memutuskan destinasi wisata Kota Sawahlunto mampu membuat wisatawan merasakan sesuatu yang luar biasa ketika berkunjung ke objek wisata ini. Hal ini dikarenakan menurut wisatawan belum semua destinasi wisata Kota Sawahlunto yang mampu menampilkan cita rasa keindahan karena sebagian destinasi merupakan hasil peninggalan sejarah pertambangan batubara yang direnovasi kemudian dijadikan sebagai kawasan wisata. Selanjutnya dari segi entertainment (hiburan) 23 orang $(76.6 \%)$ tidak setuju memutuskan ketika datang ke destinasi wisata Kota Sawahlunto dan melihat aktivitas yang dilakukan orang lain sangat menghibur untuk disaksikan. Hal ini dikarenakan aktivitas yang menarik perhatian di Kota Sawahlunto adalah ketika ada festival yang biasanya diadakan satu kali dalam setahun.

Dalam dunia pariwisata, behavioral intention dapat dikatakan sebagai kecenderungan berperilaku wisatawan untuk datang kembali mengunjungi sebuah destinasi wisata sekaligus merekomendasikannya yang diakibatkan oleh interaksi yang dilakukan wisatawan tersebut dengan suatu destinasi. Behavioral intention yang dimiliki wisatawan penting bagi sebuah destinasi wisata, disebabkan pemahaman terhadap niat wisatawan dari kedatangan berikutnya serta word of mouth yang dilakukan setelah kunjungan akan membantu memprediksi apakah wisatawan tersebut akan jadi wisatawan untuk waktu jangka panjang dan akan memberikan keuntungan untuk destinasi wisata selanjutnya (Shen et al., 2014)

Wisatawan tertarik berkunjung ke sebuah destinasi wisata untuk mendapatkan suatu pengalaman baru yang wisatawan inginkan atau untuk mendapatkan kesenangan atau kenikmatan yang berasal dari pengalaman perjalanan wisata. Mei (2014) mengatakan experience adalah sebuah sumber keunggulan bersaing yang dapat bertahan untuk waktu lama dan tidak mudah untuk ditiru. Pine dan Gilmore (1998) mengatakan experience dalam bentuk experiental economy adalah sebuah peristiwa yang melibatkan seorang individu secara personal (pribadi). Hal ini dikarenakan setiap individu akan mempunyai experience yang tidak sama untuk hal yang serupa yang dirasakan (dialami), makanya experience dikatakan bersifat individu.

Experience economy mengedepankan nilai terhadap pelanggannya. Bagaimana cara untuk menyatukan nilai produk dan nilai pelanggan yang dipadukan menjadi nilai manajemen secara maksimal. Karena, menurut Lovelock, dkk. (2015), pelanggan dapat juga memiliki ekspektasi besar jika mereka membayarkan harga yang tinggi (premium) untuk pelayanan yang berkualitas tinggi, dan akan merasa kecewa apabila pelayanan tidak terpenuhi. Sehingga, pembentukan pengalaman pelanggan harus disesuaikan dengan produk dan pelayanan yang diberikan.

Pine dan Gilmore (1998) mengatakan experiental economy terdiri atas empat yaitu education, entertainment, escapism dan esthetic. Education merupakan sebuah proses untuk mendapatkan pembelajaran akan informasi yang baru yang didapatkan oleh konsumen (pengunjung) saat berinteraksi dengan sebuah produk dan layanan jasa. Selanjutnya Entertainment merupakan gambaran kegiatan (aktivitas) yang dapat menarik perhatian seseorang untuk mendapatkan kesenangan atau kegembiraan. Sedangkan escapism merupakan suatu keadaan dimana seseorang dapat memasuki alam bawah sadar (dunia khayalan) agar dapat melupakan atau terhindar dari kenyataan yang tidak membuat mereka gembira. Kemudian esthetic merupakan tingkatan seni yang dapat menghubungan seseorang dengan cita rasa sebuah keindahan.

Selanjutnya pengalaman seseorang pada sebuah destinasi wisata akan mempengaruhi emosi, dan emosi tersebut juga akan mempengaruhi seberapa lamanya bertahan ingatan seseorang terhadap sebuah destinasi wisata yang pada akhirnya mempengaruhi kepuasan dan perilaku sebagai konsekuensinya. Emotion yang dirasakan konsumen dapat dinilai melalui kenyamanan atas pelayanan yang didapatkan oleh konsumen. Selanjutnya kenyamanan tersebut merupakan cara yang paling tepat agar dapat menentukan kepuasan dan niat konsimen untuk dapat menggunakan kembali layanan yang diberikan (Price, Arnould, \& Deibler, dalam Siwi 2018). Manthiou, $\mathrm{dkk}$ (2011) meneliti tentang Measuring the Experience Economy and The Visitors Behavioral Consequences: an Empirical Study on Veishea Event. Dari penjelasan terlihat bahwa experience economy (pengalaman ekonomi) mempengaruhi emosi pengunjung, dan akibatnya berdampak pada kepuasan 
dan niat perilaku. Selanjutnya Tsaur, Chiu dan Wang (2007) meneliti tentang The Visitors Behavioral Consequences of Experiential Marketing: An Empirical Study on Taipei Zoo. Berdasarkan hasil penelitian diperoleh experiential marketing memiliki efek positif pada emosi, emosi memiliki pengaruh yang signifikan dan positif terhadap kepuasan, kepuasan juga memiliki pengaruh yang signifikan dan positif terhadap niat perilaku, efek langsung emosi pada niat perilaku tidak signifikan, namun emosi juga memiliki efek positif pada kepuasan dan kemudian mempengaruhi niat perilaku.

Perbedaan penelitian ini dengan penelitian Manthiou, dkk (2011) dan Tsaur, Chiu dan Wang (2007) adalah dari objek yang digunakan. Penelitian Manthiou, dkk (2011) menggunakan objek veishea event. Sedangkan Tsaur, Chiu dan Wang (2007) menggunakan objek Taipei Zoo. Namun penelitian ini menggunakan objek destinasi wisata Kota Sawahlunto. Selanjutnya dari segi variabel independen yang digunakan, variabel independen penelitian ini merupakan replikasi dari variabel yang digunakan Manthiou, dkk (2011) dan Tsaur, Chiu dan Wang (2007). Namun untuk penelitian Tsaur, Chiu dan Wang (2007) mempunyai perbedaan dengan penelitian ini pada penggunaan variabel Experiential Marketing sebagai variabel independen, sementara pada penelitian ini menggunakan variabel pengalaman ekonomi (experience economy).

Kontribusi penelitian ini dapat digunakan sebagai bahan pertimbangan bagi penyedia jasa destinasi wisata umumnya, dan khususnya Kota Sawahlunto untuk menjadikan pengalaman ekonomi (experience economy) yang didapatkan wisatawan sebagai cara untuk memperbaiki dan memajukan sebuah destinasi wisata. Selain itu hasil penelitian ini berhubungan erat dengan emosi, kepuasan dan niat berperilaku sehingga sangat dibutuhkan untuk melihat bagaimana penilaian seseorang terhadap sebuah destinasi wisata.

\section{Perumusan Masalah}

Dari latar belakang yang dipaparkan tersebut, rumusan masalah yang dipergunakan dalam penelitian ini dijelaskan sebagai berikut:

1. Bagaimana pengaruh educational experience terhadap emotion wisatawan?

2. Bagaimana pengaruh entertainment experience terhadap emotion wisatawan?

3. Bagaimana pengaruh escapism experience terhadap emotion wisatawan?

4. Bagaimana pengaruh esthetics experience terhadap emotion wisatawan?

5. Bagaimana pengaruh emotion terhadap satisfaction wisatawan?

6. Bagaimana pengaruh emotion terhadap behavioral intentions wisatawan?

7. Bagaimana pengaruh satisfaction terhadap behavioral intentions wisatawan?

\section{Kerangka Teori Dan Pengembangan Hipotesis \\ Pengaruh educational experience terhadap emotion wisatawan}

Ritchie et al., (2003) mengatakan keinginan konsumen pada pengalaman yang dapat memberikan pembelajaran terus berubah mengalami peningkatan. Begitu juga yang dinyatakan Prentice (2004) bahwa permintaan wisatawan untuk mendapatkan pengalaman pribadi menjadi hal yang mendorong wisatawan untuk datang berkunjung pada sebuah destinasi. Hal ini dikarenakan educational experience (pengalaman pendidikan) mampu mempengaruhi emotion (emosi) wisatawan.

Pine dan Gilmore (1999) menyatakan education berfokus untuk menciptakan pengalaman yang dapat memberikan pendidikan sehingga mengakibatkan konsumen dapat memperoleh informasi dari peristiwa yang dialaminya, dimana keterlibatannya dapat berupa interaktif maupun fisik.

Manthiou, dkk (2011) menemukan experience economy (pengalaman ekonomi) yang terdiri dari educational, entertainment, escapism dan esthetics mempengaruhi emosi pengunjung, dan berdampak pada kepuasan dan niat perilaku.

Berdasarkan rumusan masalah, teori yang dipergunakan serta penelitian terdahulu, maka hipotesis dalam penelitian ini dapat diungkapkan sebagai berikut:

H1 : Diduga educational experience berpengaruh positif signifikan terhadap emotion wisatawan

\section{Pengaruh entertainment experience terhadap emotion wisatawan}

Pine dan Gilmore (1998) mengatakan entertainment merupakan gambaran kegiatan (aktivitas) yang dapat menarik perhatian seseorang untuk mendapatkan kesenangan atau kegembiraan. Manthiou, dkk (2011) menemukan experience economy (pengalaman ekonomi) yang terdiri dari educational, entertainment, escapism dan esthetics mempengaruhi emosi pengunjung, dan berdampak pada kepuasan dan niat perilaku.

Berdasarkan rumusan masalah, teori yang dipergunakan serta penelitian terdahulu, maka hipotesis dalam penelitian ini dapat diungkapkan sebagai berikut:
H2 : Diduga entertainment experience berpengaruh positif signifikan terhadap emotion wisatawan.

\section{Pengaruh escapism experience terhadap emotion wisatawan}

Kim et al., (2002) memberikan tanda bahwa lari dari kehidupan yang dijalani sehari-hari merupakan sesuatu yang memberikan dorongan paling sering pada warga yang tinggal diKota untuk mengunjungi sebuah destinasi wisata. Selanjutnya dengan 
mengunjungi sebuah destinasi wisata wisatawan dapat berada di tempat yang berbeda dengan kehidupan kesehariannya. Seperti yang diungkapkan Pine dan Gilmore (1998) mengatakan escapism merupakan suatu keadaan dimana seseorang dapat memasuki alam bawah sadar (dunia khayalan) agar dapat melupakan atau terhindar dari kenyataan yang tidak membuat mereka gembira. Morgan (2009) mengatakan destinasi wisata yang berjalan dengan sukses merupakan sebuah destinasi yang dapat menampilkan pada wisatan yang berkunjung kondisi dan kehidupan yang berbeda dengan kehidupan yang dijalaninya sehari-hari sehingga pengalaman yang berkesan dapat diciptakan dan dibagikan kepada orang lain.

Manthiou, dkk (2011) menemukan experience economy (pengalaman ekonomi) yang terdiri dari educational, entertainment, escapism dan esthetics mempengaruhi emosi pengunjung, dan berdampak pada kepuasan dan niat perilaku.

Berdasarkan rumusan masalah, teori yang dipergunakan serta penelitian terdahulu, maka hipotesis dalam penelitian ini dapat diungkapkan sebagai berikut:

H3 : Diduga escapism experience berpengaruh positif signifikan terhadap emotion wisatawan.

\section{Pengaruh esthetics experience terhadap emotion wisatawan}

Esthetic merupakan tingkatan seni yang dapat menghubungan seseorang dengan cita rasa sebuah keindahan. Esthetics dapat menggambarkan bahwa konsumen bisa tidak sadar akan suatu peristiwa pada lingkungan tertentu, tapi keberadaan konsumen untuk mengalami esthetics experience tidak aktif namun bersifat pasif. Hal ini menunjukkan konsumen tidak dapat memberi pengaruh apapun pada peristiwa yang terjadi, sehingga ini membawa pada pengalaman yang akan melibatkan unsur perasaan (Pine \& Gilmore, 1998).

Manthiou, dkk (2011) menemukan experience economy (pengalaman ekonomi) yang terdiri dari educational, entertainment, escapism dan esthetics mempengaruhi emosi pengunjung, dan berdampak pada kepuasan dan niat perilaku.

Berdasarkan rumusan masalah, teori yang dipergunakan serta penelitian terdahulu, maka hipotesis dalam penelitian ini dapat diungkapkan sebagai berikut:

H4 : Diduga esthetics experience berpengaruh positif signifikan terhadap emotion wisatawan

\section{Pengaruh emotion terhadap satisfaction wisatawan}

Konsumen melakukan pembelian dan menggunakan produk atau jasa bukan hanya karena nilai fungsinya, melainkan juga disebkan nilai sosial dan emosi yang dimiliki produk atau jasa tersebut. Hal ini menunjukkan bahwa pembelian atas produk atau jasa dilakukan karena dasar kemampuan produk untuk merangsang dan memuaskan emosi yang dirasakan. Dimana emosi yang dirasakan bisa positif atau negatif yang keduanya dapat jadi pengalaman yang menyenangkan bagi konsumen. Selanjutnya emosi berperan penting pada tahap purnabeli, karena konsumen tidak sekedar merasakan kepuasan atau sebaliknya tapi juga berbagi akan emosi yang dirasakan berupa perasaan marah, perasaan jengkel, kesal ataupun sedih (Tjiptono, 2014). Tsaur, Chiu dan Wang (2007) menemukan emosi memiliki pengaruh yang signifikan dan positif terhadap kepuasan.

Berdasarkan rumusan masalah, teori yang dipergunakan serta penelitian terdahulu, maka hipotesis dalam penelitian ini dapat diungkapkan sebagai berikut:

H5 : Diduga emotion berpengaruh positif signifikan terhadap satisfaction wisatawan.

\section{Pengaruh emotion terhadap behavioral intentions wisatawan}

Emosi merupakan keinginan agar mendapatkan sebuah perasaan kepuasan pada produk atau layanan jasa yang digunakan. Produk yang dimaksudkan adalah produk yang mampu mempengaruhi perasaan dan emosi konsumen sehingga membentuk hubungan yang dalam dan bertahan lama dan mengakibatkan konsumen berniat menggunakan produk itu kembali (Wijanarka, 2014).

Emotion yang dirasakan konsumen dapat dinilai melalui kenyamanan atas pelayanan yang didapatkan oleh konsumen. Selanjutnya kenyamanan tersebut merupakan cara yang paling tepat agar dapat menentukan kepuasan dan niat konsimen untuk dapat menggunakan kembali layanan yang diberikan (Price, Arnould, \& Deibler, dalam Siwi 2018). Selanjutnya perubahan emosi pada pelanggan terjadi setiap saat, ketika seorang pelanggan mengalami emosi positif dalam pelayanan yang diberikan, pelanggan akan mengungkapkan tingkat kepuasan dan memiliki niat pembelian kembali yang lebih tinggi kepada perusahaan tersebut dan cenderung menolak penawaran pesaing (Liang et al., 2012).

Berdasarkan rumusan masalah, teori yang dipergunakan serta penelitian terdahulu, maka hipotesis dalam penelitian ini dapat diungkapkan sebagai berikut:
H6 : Diduga emotion berpengaruh positif signifikan terhadap behavioral intentions wisatawan

\section{Pengaruh satisfaction terhadap behavioral intentions wisatawan}

Kepuasan wisatawan merupakan sesuatu yang sangat penting dalam pemberian atas layanan produk dan jasa sebuah tempat wisata, kepuasan tersebut dapat dipergunakan untuk merencanakan pemasaran, 
karena kepuasan dapat dijadikan alat ukur untuk evaluasi dari kinerja produk pariwisata yang diberikan (Sofi et al, 2014). Hal ini dikarenakan ketidakpuasan para pengunjung destinasi wisata terhadap hal yang kecil juga dapat mempengaruhi keinginan wisatawan untuk berkunjung atau datang kembali serta merekomendasikan tempat wisata kepada orang lain atau kerabatnya (Pizman dkk, 2009). Hal ini mengindikasikan bahwa kepuasan wisatawan berpengaruh terhadap niat berkunjung kembali wisatawan.

Tsaur, Chiu dan Wang (2007) menemukan kepuasan juga memiliki pengaruh yang signifikan dan positif terhadap niat perilaku. Sulanjari dan Roostika (2018) menemukan kepuasan wisatawan berpengaruh positif terhadap niat perilaku serta Ali, dkk (2015) juga menemukan satisfaction berpengaruh positif terhadap behavioural intentions.

Berdasarkan rumusan masalah, teori yang dipergunakan serta penelitian terdahulu, maka hipotesis dalam penelitian ini dapat diungkapkan sebagai berikut:

H7 : Diduga satisfaction berpengaruh positif signifikan terhadap behavioral intentions wisatawan.

\section{Kerangka Konseptual}

Pengunjung memiliki beragam motivasi untuk sebuah destinasi wisata. Seseorang mengunjungi destinasi wisata karena alasan yang berbeda dan bahwa mayoritas pergi ke destinasi wisata tertentu untuk apa yang ditawarkan daripada ke destinasi wisata secara umum. Pengalaman seseorang pada sebuah destinasi wisata mempengaruhi kepuasan dan memainkan peran penting dalam bertahan dan mencapai keunggulan kompetitif dalam industri pariwisata. Pengalaman yang diinginkan dapat memengaruhi emosi, sehingga bertahan lama di benak pelanggannya dan memengaruhi perilaku sebagai konsekuensinya.

Dalam penelitian ini pengalaman dilihat dari experience economy (pengalaman ekonomi) yang mencakup pengalaman education (pendidikan), pengalaman entertainment (hiburan), pengalaman escapism (pelarian), dan pengalaman esthetic (estetika). Menurut pengalaman ekonomi, konsumen mencari pengalaman unik di luar dari hanya mengonsumsi produk dan layanan karena tingkat kualitas produk dan layanan yang tinggi dan konsisten tidak dapat lagi digunakan untuk membedakan pilihan bagi konsumen. Pengalaman didefinisikan sebagai hasil pertemuan, menjalani, atau hidup melalui situasi yang memberikan nilai-nilai sensorik, emosional, kognitif, perilaku, relasional dan fungsional. Sementara emosi adalah kesadaran akan terjadinya beberapa rangsangan fisiologis yang diikuti oleh respons perilaku bersama dengan menilai makna keduanya. Emotion pada konsumen perlu diukur dengan kenyamanan pada pelayanan yang diberikan pada konsumen itu sendiri. Kenyamanan dalam pelayanan yang diberikan pada konsumen merupakan cara yang efektif untuk menentukan tingkat kepuasan dan niat untuk menggunakan kembali pelayanan itu. Penyedia pelayanan saat ini memiliki peran yang sangat penting baik pada perusahaan jasa maupun non jasa, karena pelayanan membutuhkan kerja keras untuk menciptakan rasa menyenangkan atau perasaan yang positif terhadap konsumen.

Dari rumusan masalah, tujuan penelitian serta landasan teori yang dipergunakan, maka dapat dibuat kerangka pemikiran untuk menunjang hasil penelitian sebagai berikut:

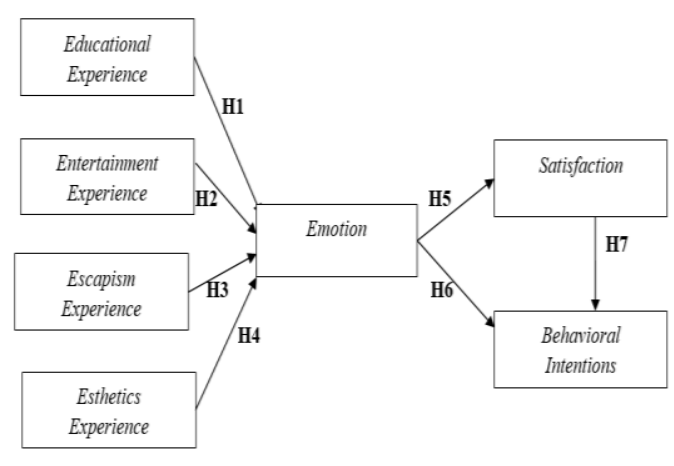

Gambar 1. Kerangka Konseptual

Mengukur Experience Economy dan Perilaku Pengunjung: Studi Empiris Pada Destinasi Wisata Kota Sawahlunto

\section{Metode Penelitian}

Jenis penelitian berdasarkan metode yang digunakan merupakan metode penelitian kuantitatif (Sugiyono, 2014). Populasinya merupakan seluruh wisatawan yang berkunjung ke destinasi wisata Kota Sawahlunto tahun 2019 yang tidak diketahui dengan pasti jumlahnya, untuk mendapatkan jumlah sampel digunakan pendekatan rumus Chocran dalam (Sarwono, 2012) dengan jumlah sampel sebanyak 246 orang wisatawan yang berkunjung ke destinasi wisata Kota Sawahlunto tahun 2019. Metode yang dipergunakan dalam pengambilan sampel metode nonprobability sampling dengan teknik accidental sampling (Sugiyono, 2014). Metode analisa data menggunakan Partial Least Square (PLS).

\subsection{Definisi Operasional Variabel}

Pada penelitian ini ukuran variabel mempergunakan skala likert, selanjutnya dapat dijelaskan defenisi variabel sebagai berikut:

\section{Experince Economy}

Experience economy (pengalaman ekonomi) adalah sebuah konsep dimana perusahaan dapat memulai sebuah permulaan yang baru dengan menciptakan sebuah pengalaman yang berkesan bagi masing-masing konsumen. Experience 
merupakan peristiwa yang mengikat individual secara personal; tetapi diduga bahwa definisi experience dari perspektif konsumen sebagai sesuatu yang menyenangkan, mengikat, tidak dapat dilupakan karena mengkonsumsi hal-hal yang berhubungan dengan experience tersebut (Christianto, 2013)

2. Emotion

Emosi didefinisikan sebagai keadaan mental internal yang difokuskan pada pengaruh (Ortony, dkk dalam Manthiou, dkk, 2011)

3. Satisfation

Kepuasan merupakan persepsi individu dari performa produk/jasa dalam hubungannya dengan harapan yang muncul setelah membandingkan kinerja yang dipersepsikan terhadap kinerja yang diharapkan (Kotler dan Keller, 2009)

4. Behavioral Intention

Behavioral Intention merupakan penilaian pengunjung tentang niat keinginan untuk berkunjung kembali ke suatu destinasi yang sama dan kesediaan untuk merekomendasikan destinasi tersebut kepada orang lain (Spears \& Singh, 2004).

Kemudian untuk indikator dari variabel yang dipergunakan sebagai berikut:

TABEL 3

TABEL OPERASIONAL VARIABEL

\begin{tabular}{|c|c|c|}
\hline No & Variabel & Indikator \\
\hline \multirow[t]{22}{*}{1} & Experience & 1. Merangsang rasa ingin tahu \\
\hline & Economy & saya \\
\hline & & 2. Tingkatkan pengetahuan saya \\
\hline & - Education & 3. Meningkatkan filosofi hidup \\
\hline & - Entertainment & saya \\
\hline & $\begin{array}{l}\text { - Escapism } \\
\text { - Esthetics }\end{array}$ & $\begin{array}{l}\text { 4. Bisa membagikan pengalaman } \\
\text { saya dengan keluarga dan } \\
\text { teman }\end{array}$ \\
\hline & & $\begin{array}{l}\text { Loureiro (2014) dan Radder, dkk } \\
\text { (2015) }\end{array}$ \\
\hline & & $\begin{array}{l}\text { 1. Berinteraksi dengan orang lain } \\
\text { di destinasi wisata }\end{array}$ \\
\hline & & 2. Rileks secara fisik \\
\hline & & $\begin{array}{l}\text { 3. Merasa terstimulasi secara } \\
\text { emosional }\end{array}$ \\
\hline & & 4. Menyenangkan \\
\hline & & $\begin{array}{l}\text { 5. Memiliki pengalaman yang } \\
\text { tidak biasa }\end{array}$ \\
\hline & & $\begin{array}{l}\text { Loureiro (2014) dan Radder, dkk } \\
\text { (2015) }\end{array}$ \\
\hline & & $\begin{array}{l}\text { Jadilah orang lain saat berada di } \\
\text { destinasi wisata }\end{array}$ \\
\hline & & $\begin{array}{l}\text { 2. Bayangkan hidup di waktu dan } \\
\text { tempat yang berbeda }\end{array}$ \\
\hline & & 3. Lari dari kenyataan \\
\hline & & 4. Menjauh dari kerumunan orang \\
\hline & & $\begin{array}{l}\text { 5. Menjauh dari lingkungan sosial } \\
\text { yang penuh tekanan }\end{array}$ \\
\hline & & $\begin{array}{l}\text { Loureiro (2014) dan Radder, dkk } \\
(2015)\end{array}$ \\
\hline & & $\begin{array}{l}\text { 1. Rasa harmoni dengan } \\
\text { lingkungan }\end{array}$ \\
\hline & & $\begin{array}{l}\text { 2. Lingkungan fisik yang } \\
\text { menyenangkan }\end{array}$ \\
\hline & & $\begin{array}{l}\text { 3. Destinasi wisata yang } \\
\text { menyenangkan }\end{array}$ \\
\hline
\end{tabular}

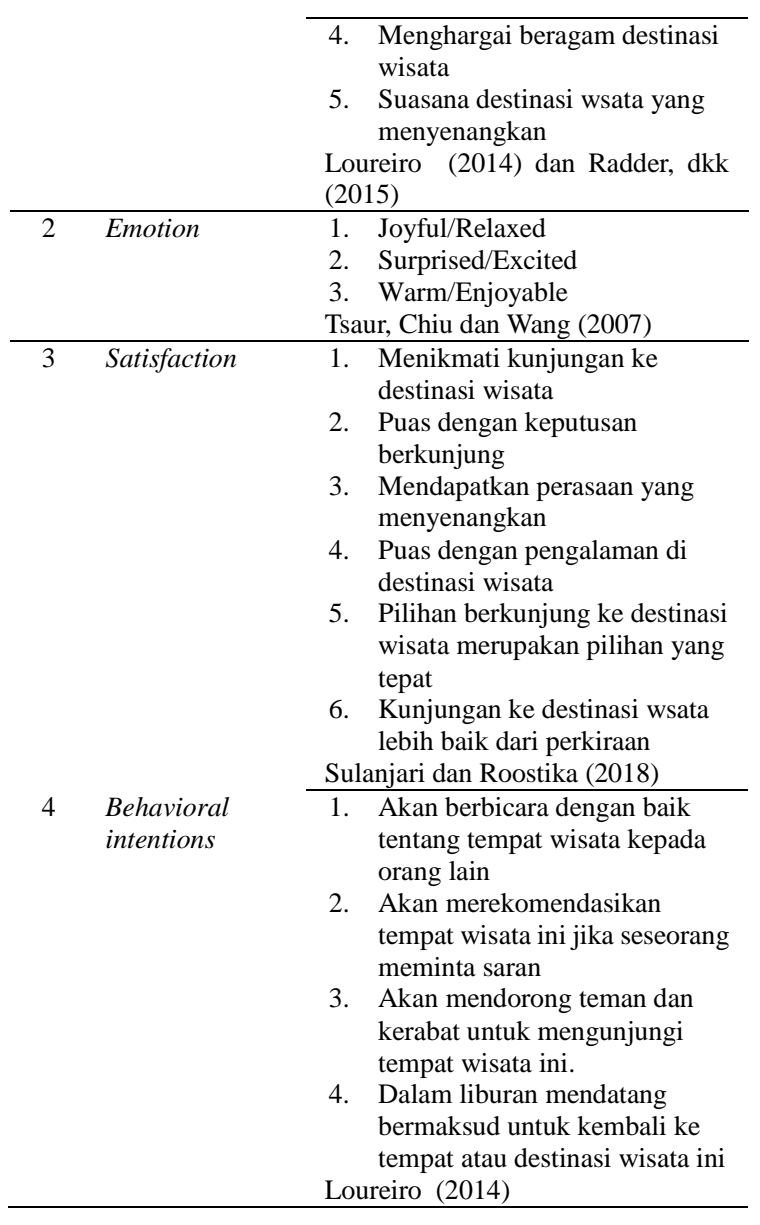

\section{Analisis Data}

Penganalisisan data menggunakan pendekatan Partial Least Square (PLS). Berikut dapat dijelaskan hasil pengolahan data untuk melihat hasil analisis PLS Algorithm.

\subsection{Model Pengukuran (Outer Model)}

Outer model mendefenisikan bagaimana hubungan setiap Blok indikator dengan variabel latennya (Ghozali, 2014). Dimana jika menggunakan indikator refleksif dievaluasi dengan convergent serta discriminant validity dari indikatornya dan composite reliability untuk Blok indikator (Ghozali, 2014)

\subsubsection{Convergent Validity}

Dari hasil output data untuk melihat korelasi antara indikator dengan konstruknya, maka dapat dijelaskan bahwa jika mengacu pada nilai outer loading awal yang disyaratkan sebesar 0,50 maka satu butir item pernyataan education yaitu education 3 , kemudian dua butir item pernyataan entertainment yaitu entertainment 1 dan 2 belum memenuhi yang disyaratkan, dimana nilai masing-masing outer loading untuk setiap item pernyataan $<0,50$, sehingga dikeluarkan atau dihapuskan serta uji validitas konstruk tersebut diulang kembali.

Selanjutnya dari data juga dapat dijelaskan jika 
mengacu pada nilai outer loading awal yang disyaratkan sebesar 0,50 maka semua item pernyataan hasil pengulangan tahap kedua pada penelitian ini sudah memenuhi yang disyaratkan, dimana nilai masing-masing outer loading untuk setiap item pernyataan $>0,50$, sehingga semua item pernyataan dinyatakan seluruhnya valid seperti yang dikemukakan (Ghozali, 2014).

\subsubsection{Discriminant validity}

Hasil olahan untuk discriminant validity dalam penelitian ini dapat dijelaskan bahwa korelasi konstruk behavioral intentions, education, emotion, entertainment, escapism, esthetics dan satisfaction dengan indikatornya lebih tinggi dibanding korelasi indikatornya dengan konstruk lainnya. Hal ini menunjukkan bahwa konstruk laten memprediksi ukuran pada Blok mereka lebih baik daripada ukuran pada Blok lainnya (Ghozali, 2014).

\subsubsection{Reliabilitas Konstruk (Reliability Construct)}

Berdasarkan data dapat dijelaskan hasil pengolahan data untuk reliabilitas konstruk yang diukur menggunakan composite reliability dan cronbach's Alpha. Dari data dapat dijelaskan nilai composite reliability dan cronbach's Alpha untuk semua konstruk behavioral intentions, education, emotion, entertainment, escapism, esthetics dan satisfaction besar dari 0,70 . Hal ini menggambarkan bahwa semua konstruk yang dipergunakan pada model yang diestimasi memenuhi kriteria reliabel. Hal ini sesuai dengan pendapat (Ghozali, 2014) yang menyatakan konstruk dapat dinyatakan reliable jika nilai composite reliability dan cronbach alpha besar dari 0,70 .

4.2 Pengujian Model Struktural (Inner model) Dari hasil pengolahan pada data, diperoleh hasil pengolahan data R-square pada tabel 5 berikut:

TABEL 5

\begin{tabular}{|l|r|}
\hline \multicolumn{2}{|c}{ R-SQUARE } \\
\hline behavioral intentions & R Square \\
\hline emotion & 0,483 \\
\hline satisfaction & 0,416 \\
\hline
\end{tabular}

Sumber : Pengolahan data dari PLS, 2019

Dari hasil pengolahan data dapat dijelaskan bahwa nilai $\mathrm{R}$ Square pada tabel 5 menunjukkan bahwa behavioral intentions dipengaruhi oleh education, entertainment, escapism, esthetics, emotion dan satisfaction sebesar 0,483. Selanjutnya emotion dipengaruhi oleh education, entertainment, escapism, serta esthetics sebesar 0,416 dan satisfaction dipengaruhi oleh education, entertainment, escapism, esthetics, dan emotion sebesar 0,463.

Selain menjelaskan nilai R-square, model PLS juga bisa dipergunakan untuk menjelaskan nilai Q-square predictive relevance untuk model konstruk, dimana Q-square dipergunakan untuk mengukur seberapa baik nilai observasi dihasilkan oleh model dan juga estimasi parameternya (Chin dalam Ghozali, 2014). Perhitungan Q-Square dilakukan dengan rumus:

$\mathrm{Q} 2=1-(1-\mathrm{R} 12)(1-\mathrm{R} 22)(1-\mathrm{R} 32) \ldots \ldots \ldots . .(1-\mathrm{Rp} 2)$

$\mathrm{Q}^{2}=1-(1-0,483)(1-0,416)(1-0,463)$

$\mathrm{Q}^{2}=0,8379$

Dari hasil data dapat dijelaskan bahwa nilai predictive - relevance sebesar 0,8379 dimana nilai ini lebih besar dari 0 , sehingga dapat dijelaskan bahwa $83,79 \%$ variasi pada variabel intensi keluar behavioral intentions yang dapat dijelaskan variabel yang digunakan pada model dan $16,21 \%$ dijelaskan oleh faktor-faktor lain diluar model yang tidak dipergunakan dalam penelitian ini. Dengan hasil yang didapatkan maka dapat disimpulkan model memiliki nilai predictive relevance.

\section{Pengujian Hipotesis dan Pembahasan}

\subsection{Pengaruh Langsung}

Hasil pengujian data untuk melihat pengaruh langsung dengan menggunakan bootstrapping dari analisis PLS dapat dilihat pada tabel berikut ini :

TABEL 6

Hasil Pengolahan Data Untuk Path CoefFicients

MengGunaKan Metode PLS

UNTUK PENGARUH LANGSUNG

\begin{tabular}{|l|c|c|c|}
\hline & $\begin{array}{c}\text { Original } \\
\text { Sample (O) }\end{array}$ & $\begin{array}{c}\text { T Statistics } \\
(\mid \text { O/STERR } \mid)\end{array}$ & $\begin{array}{c}\text { P } \\
\text { Values }\end{array}$ \\
\hline $\begin{array}{l}\text { education -> } \\
\text { emotion }\end{array}$ & 0,214 & 3,161 & 0,002 \\
\hline $\begin{array}{l}\text { emotion } \\
\text { behavioral } \\
\text { intentions }\end{array}$ & 0,520 & 6,474 & 0,000 \\
\hline $\begin{array}{l}\text { emotion -> } \\
\text { satisfaction }\end{array}$ & 0,681 & 10,737 & 0,000 \\
\hline $\begin{array}{l}\text { entertainment } \\
\text { - emotion }\end{array}$ & 0,098 & 1,450 & 0,148 \\
\hline $\begin{array}{l}\text { escapism } \\
\text { emotion }\end{array}$ & 0,233 & 3,859 & 0,000 \\
\hline $\begin{array}{l}\text { esthetics } \\
\text { emotion }\end{array}$ & 0,365 & 6,099 & 0,000 \\
\hline
\end{tabular}




\begin{tabular}{|l|l|l|l|}
\hline $\begin{array}{l}\text { satisfaction -> } \\
\text { behavioral } \\
\text { intentions }\end{array}$ & 0,228 & 2,709 & 0,007 \\
\hline
\end{tabular}

Sumber: Pengolahan data dengan PLS, 2019

Dari hasil pengolahan data penelitian yang terlihat pada tabel 6 maka hasil data tersebut dapat diuraikan sebagai berikut :

\section{a. Pengaruh educational experience terhadap emotion wisatawan}

Dari hasil pengujian hipotesis diperoleh nilai uji T-statistic educational experience terhadap emotion wisatawan > 1,96 yaitu sebesar 3,161 serta nilai signifikasinya sebesar $0,002<0,05$, dengan path educational experience bernilai positif sebesar 0,214, sehingga dapat ditarik kesimpulan educational experience berpengaruh positif signifikan terhadap emotion wisatawan pada destinasi wisata Kota Sawahlunto. Hal ini menunjukkan bahwa educational experience merupakan hal yang dapat mempengaruhi emotion wisatawan, dimana semakin baik education maka akan semakin meningkat emotion wisatawan pada destinasi wisata Kota Sawahlunto.

Hal ini mengindikasikan education mampu mempengaruhi emotion wisatawan untuk memperoleh suatu kepuasan pada suatu produk atau layanan jasa yang digunakan. Hal ini dikarenakan dengan educational experience (pengalaman pendidikan) wisatawan dapat berpartisipasi aktif melalui pikirannya untuk penyerapan informasi baru yang dialami wisatawan saat mengunjungsi sebuah destinasi wisata sehingga mempengaruhi emotion (emosi) wisatawan. Selanjutnya educational experience (pengalaman pendidikan) yang didapatkan wisatawan pada destinasi wisata Kota Sawahlunto dapat dilihat dari ketika berbagai destinasi wisata mampu merangsang rasa ingin tahu wisatawan serta mampu meningkatkan pengetahuan wisatawan akan produk pariwisata dan wisatawan bisa membagikan pengalamannya dengan keluarga dan teman mengenai destinasi wisata Kota Sawahlunto.

Ritchie et al., (2003) mengatakan keinginan konsumen pada pengalaman yang dapat memberikan pembelajaran terus berubah mengalami peningkatan. Begitu juga yang dinyatakan Prentice (2004) bahwa permintaan wisatawan untuk mendapatkan pengalaman pribadi menjadi hal yang mendorong wisatawan untuk datang berkunjung pada sebuah destinasi. Hal ini dikarenakan educational experience (pengalaman pendidikan) mampu mempengaruhi emotion (emosi) wisatawan.

Pine dan Gilmore (1999) menyatakan education berfokus untuk menciptakan pengalaman yang dapat memberikan pendidikan sehingga mengakibatkan konsumen dapat memperoleh informasi dari peristiwa yang dialaminya, dimana keterlibatannya dapat berupa interaktif maupun fisik. Hasil penelitian ini sejalan dengan penelitian Manthiou, dkk (2011) yang menemukan experience economy (pengalaman ekonomi) yang terdiri dari educational, entertainment, escapism dan esthetics mempengaruhi emosi pengunjung, dan berdampak pada kepuasan dan niat perilaku.

\section{b. Pengaruh entertainment experience terhadap emotion wisatawan}

Dari hasil pengujian hipotesis diperoleh nilai uji T-statistic entertainment terhadap emotion wisatawan $<$ 1,96 yaitu sebesar 1,450 serta nilai signifikansinya $0,148>0,05$, dengan path coefficien entertainment bernilai positif sebesar 0,098 , sehingga dapat ditarik kesimpulan entertainment tidak berpengaruh positif signifikan terhadap emotion wisatawan pada destinasi wisata Kota Sawahlunto. Hal ini menunjukkan bahwa entertainment bukan hal yang dapat mempengaruhi emotion wisatawan.

Selanjutkan dapat dijelaskan bahwa wisatawan yang mengunjungi destinasi atau tempat wisata yang ada di Kota Sawahlunto tidak mempertimbangkan entertainment berupa destinasi wisata mampu membuat wisatawan merasa terstimulasi secara emosional serta merasa menyenangkan untuk dikunjungi, selain itu juga wisatawan memiliki pengalaman yang tidak biasa di destinasi atau tempat wisata di Kota Sawahlunto, hal ini disebabkan adanya faktor lainnya yang dapat mempengaruhi emotion wisatawan sehingga dapat mengubah emotion wisatawan pada destinasi atau tempat wisata yang dikunjunginya. Hal ini dapat disebabkan karena sudah pernah atau belumnya destinasi atau tempat wisata tersebut dikunjungi, kemudian tepat atau tidaknya waktu untuk mengunjungi sebuah destinasi atau tempat wisata. Entertainment experience (pengalaman hiburan) dapat timbul ketika seseorang mengamati secara pasif kegiatan (aktifitas) yang tidak berhubungan dengan dirinya. Pengunjung sebuah 
destinasi wisata membutuhkan pengalaman hiburan dengan menikmati segala aktifitas yang ada pada sebuah destinasi wisata. Pine dan Gilmore (1998) mengatakan entertainment merupakan gambaran kegiatan (aktivitas) yang dapat menarik perhatian seseorang untuk mendapatkan kesenangan atau kegembiraan. Hasil penelitian ini tidak sejalan dengan penelitian Manthiou, dkk (2011) yang menemukan experience economy (pengalaman ekonomi) yang terdiri dari educational, entertainment, escapism dan esthetics mempengaruhi emosi pengunjung, dan berdampak pada kepuasan dan niat perilaku.

\section{c. Pengaruh escapism experience terhadap emotion wisatawan}

Dari hasil pengujian hipotesis diperoleh nilai uji T-statistic escapism experience terhadap emotion wisatawan > 1,96 yaitu sebesar 3,859 serta nilai signifikansinya sebesar $0,000<0,05$, dengan path coefficien escapism bernilai positif sebesar 0,233, sehingga dapat ditarik kesimpulan escapism berpengaruh positif signifikan terhadap emotion wisatawan pada destinasi wisata Kota Sawahlunto. Hal ini menunjukkan bahwa escapism merupakan hal yang dapat mempengaruhi emotion wisatawan, dimana semakin baik escapism maka semakin meningkat emotion wisatawan pada destinasi wisata Kota Sawahlunto.

Selanjutkan dapat dijelaskan bahwa emotion wisatawan pada destinasi atau tepat wisata di Kota Sawahlunto ditentukan oleh escapism experience (pengalaman pelarian) yang didapatkan saat datang berkunjung pada destinasi atau tempat wisata tersebut. Jika suatu destinasi wisata mampu memberikan escapism experience (pengalaman pelarian) yang baik terlihat dari wisatawan bisa menjadi orang lain saat berada di destinasi wisata, kemudian ketika berada di destinasi wisata tersebut wisatawan bisa membayangkan hidup di waktu dan tempat yang berbeda dan juga bisa lari dari kenyataan hidup yang sedang hadapi, serta bisa menjauh dari kerumunan orang dan juga menjauh dari lingkungan sosial yang penuh tekanan maka akan mempengaruhi emotion wisatawan pada destinasi wisata Kota Sawahlunto.

Kim et al., (2002) memberikan tanda bahwa lari dari kehidupan yang dijalani sehari-hari merupakan sesuatu yang memberikan dorongan paling sering pada warga yang tinggal diKota untuk mengunjungi sebuah destinasi wisata. Selanjutnya dengan mengunjungi sebuah destinasi wisata wisatawan dapat berada di tempat yang berbeda dengan kehidupan kesehariannya. Seperti yang diungkapkan Pine dan Gilmore (1998) mengatakan escapism merupakan suatu keadaan dimana seseorang dapat memasuki alam bawah sadar (dunia khayalan) agar dapat melupakan atau terhindar dari kenyataan yang tidak membuat mereka gembira. Morgan (2009) mengatakan destinasi wisata yang berjalan dengan sukses merupakan sebuah destinasi yang dapat menampilkan pada wisatan yang berkunjung kondisi dan kehidupan yang berbeda dengan kehidupan yang dijalaninya sehari-hari sehingga pengalaman yang berkesan dapat untuk diciptakan dan dibagikan kepada orang lain.

Hasil penelitian ini sejalan dengan penelitian Manthiou, dkk (2011) yang menemukan experience economy (pengalaman ekonomi) yang terdiri dari educational, entertainment, escapism dan esthetics mempengaruhi emosi pengunjung, dan berdampak pada kepuasan dan niat perilaku.

\section{d. Pengaruh esthetics experience terhadap emotion wisatawan}

Dari hasil pengujian hipotesis diperoleh nilai uji T-statistic esthetics experience terhadap emotion wisatawan > 1,96 yaitu sebesar 6,099 serta nilai signifikansinya sebesar $0,000<0,05$, dengan nilai path coefficien esthetics bernilai positif sebesar 0,365, sehingga dapat ditarik kesimpulan esthetics berpengaruh positif signifikan terhadap emotion wisatawan pada destinasi wisata Kota Sawahlunto. Hal ini menunjukkan bahwa esthetics merupakan hal yang dapat mempengaruhi emotion wisatawan, dimana semakin baik esthetics maka semakin meningkat emotion wisatawan pada destinasi atau tempat wisata di Kota Sawahlunto.

Hal ini mengindikasikan emotion wisatawan pada destinasi wisata Kota Sawahlunto ditentukan oleh esthetics experience (pengalaman estetika) yang didapatkan saat mengunjungi destinasi wisata tersebut. Dimana ketika suatu destinasi wisata mampu memberikan esthetics experience (pengalaman estetika) yang baik terlihat dari ketika wisatawan berada di destinasi wisata wisatawan bisa merasakan memiliki harmoni dengan lingkungan, kemudian destinasi wisata memiliki lingkungan fisik yang menyenangkan, serta tempat-tempat destinasi wisata berbeda dari destinasi wisata pada umumnya, dan wisatawan menghargai beragam destinasi wisata dan juga destinasi suasana destinasi wisata menyenangkan dibandingkan suasana destinasi wisata lainnya maka akan mempengaruhi emotion wisatawan pada destinasi wisata Kota Sawahlunto.

Esthetic merupakan tingkatan seni yang dapat menghubungan seseorang dengan cita rasa sebuah keindahan. Esthetics dapat menggambarkan bahwa konsumen bisa tidak sadar akan suatu peristiwa pada lingkungan tertentu, tapi keberadaan konsumen untuk mengalami esthetics experience tidak aktif namun bersifat pasif. Hal ini menunjukkan konsumen tidak dapat memberi pengaruh apapun pada peristiwa yang terjadi, sehingga ini membawa pada pengalaman yang 
akan melibatkan unsur perasaan (Pine \& Gilmore, 1998).

Hasil penelitian ini sejalan dengan penelitian Manthiou, dkk (2011) yang menemukan experience economy (pengalaman ekonomi) yang terdiri dari educational, entertainment, escapism dan esthetics mempengaruhi emosi pengunjung, dan berdampak pada kepuasan dan niat perilaku.

\section{e. Pengaruh emotion terhadap satisfaction wisatawan}

Dari hasil pengujian hipotesis diperoleh nilai uji T-statistic emotion terhadap satisfaction wisatawan > 1,96 yaitu sebesar 10,737 serta nilai signifikansinya sebesar $0,000<0,05$ dengan nilai path coefficien bernilai positif sebesar 0,681 sehingga dapat ditarik kesimpulan emotion berpengaruh positif signifikan terhadap satisfaction wisatawan pada destinasi wisata Kota Sawahlunto. Hal ini menunjukkan bahwa emotion merupakan hal yang dapat mempengaruhi satisfaction wisatawan, dimana semakin baik emotion wisatawan pada destinasi wisata maka semakin baik pula satisfaction wisatawan pada destinasi atau tempat wisata di Kota Sawahlunto.

Hal ini mengindikasikan satisfaction wisatawan pada destinasi wisata Kota Sawahlunto ditentukan oleh emotion wisatawan yang didapatkan saat mengunjungi destinasi wisata tersebut. Dimana ketika suatu destinasi wisata mampu memberikan rangsangan terhadap emotion para wisatawan yang berkunjung baik dari segi wisatawan merasa gembira (joyful), merasa jadi ceria (cheerful), merasa rileks (relaxed), merasa terkejut (surprised) dengan keindahan, merasa heran (astonished) dengan kemampuan pemerintah mengubah bekas pertambangan batu bara menjadi tempat destinasi wisata, merasa mendapatkan kehangatan (satisfied), dan merasa mendapatkan suasana yang menyenangan (enjoyable) ketika berkunjung maka akan mempengaruhi satisfaction wisatawan pada destinasi wisata Kota Sawahlunto.

Konsumen melakukan pembelian dan menggunakan produk atau jasa bukan hanya karena nilai fungsinya, melainkan juga disebabkan nilai sosial dan emosi yang dimiliki produk atau jasa tersebut. Hal ini menunjukkan bahwa pembelian atas produk atau jasa dilakukan karena dasar kemampuan produk untuk merangsang dan memuaskan emosi yang dirasakan. Dimana emosi yang dirasakan bisa positif atau negatif yang keduanya dapat jadi pengalaman yang menyenangkan bagi konsumen. Selanjutnya emosi berperan penting pada tahap purnabeli, karena konsumen tidak sekedar merasakan kepuasan atau sebaliknya tapi juga berbagi akan emosi yang dirasakan berupa perasaan marah, perasaan jengkel, kesal ataupun sedih (Tjiptono, 2014). Hasil penelitian ini sejalan dengan hasil penelitian Tsaur, Chiu dan Wang (2007) yang menemukan emosi memiliki pengaruh yang signifikan dan positif terhadap kepuasan.

\section{f. Pengaruh emotion terhadap behavioral intentions wisatawan}

Dari hasil pengujian hipotesis didapatkan bahwa nilai uji T-statistic emotion terhadap behavioral intentions wisatawan $>1,96$ yaitu sebesar 6,474 serta nilai signifikansinya sebesar $0,000<0,05$, dengan nilai path coefficien bernilai positif sebesar 0,520 . Sehingga dapat ditarik kesimpulan emotion berpengaruh positif signifikan terhadap behavioral intentions wisatawan pada destinasi wisata Kota Sawahlunto. Hal ini menunjukkan bahwa emotion merupakan hal yang mempengaruhi behavioral intentions wisatawan dimana semakin baik emotion wisatawan pada destinasi wisata maka semakin baik pula behavioral intentions wisatawan pada destinasi wisata Kota Sawahlunto.

Emosi merupakan keinginan agar mendapatkan sebuah perasaan kepuasan pada produk atau layanan jasa yang digunakan. Produk yang dimaksudkan adalah produk yang mampu mempengaruhi perasaan dan emosi konsumen sehingga membentuk hubungan yang dalam dan bertahan lama dan mengakibatkan konsumen berniat menggunakan produk itu kembali (Wijanarka, 2014). Emotion wisatawan terhadap destinasi wisata Kota Sawahlunto terlihat dari wisatawan merasa gembira (joyful), merasa jadi ceria (cheerful), merasa rileks (relaxed), merasa terkejut (surprised) dengan keindahan, merasa heran (astonished) dengan kemampuan pemerintah mengubah bekas pertambangan batu bara menjadi tempat destinasi wisata, merasa mendapatkan kehangatan (satisfied), dan merasa mendapatkan suasana yang menyenangan (enjoyable) ketika berkunjung, sehingga pada akhirnya emotion wisatawan tersebut akan mempengaruhi behavioral intentions wisatawan pada destinasi wisata Kota Sawahlunto.

Emotion yang dirasakan konsumen dapat dinilai melalui kenyamanan atas pelayanan yang didapatkan oleh konsumen. Selanjutnya kenyamanan tersebut merupakan cara yang paling tepat agar dapat menentukan kepuasan dan niat konsimen untuk dapat menggunakan kembali layanan yang diberikan (Price, Arnould, \& Deibler, dalam Siwi 2018). Selanjutnya perubahan emosi pada pelanggan terjadi setiap saat, ketika seorang pelanggan mengalami emosi positif dalam pelayanan yang diberikan, pelanggan akan mengungkapkan tingkat kepuasan dan memiliki niat pembelian kembali yang lebih tinggi kepada perusahaan tersebut dan cenderung menolak penawaran pesaing (Liang et al., 2012).

\section{g. Pengaruh satisfaction terhadap behavioral intentions wisatawan}

Berdasarkan hasil uji hipotesis ditemukan bahwa satisfaction berpengaruh positif signifikan terhadap behavioral intentions wisatawan pada destinasi wisata Kota Sawahlunto dengan nilai uji 
T-statistic > 1,96 yaitu sebesar 2,709 serta sig 0,007 < 0,05 . Selain itu, satisfaction memiliki nilai path coefficien bernilai positif sebesar 0,228. Dengan demikian maka satisfaction merupakan hal yang mempengaruhi behavioral intentions wisatawan pada destinasi wisata Kota Sawahlunto dimana semakin baik satisfaction wisatawan maka semakin baik behavioral intentions wisatawan pada destinasi wisata Kota Sawahlunto.

Kepuasan wisatawan merupakan perbandingan pengalaman yang didapatkan wisatawan ketika berada di tempat wisata dengan harapan terhadap tempat wisata yang dimaksudkan (Das, D \&Sharma. S.K, 2005). Hal ini dapat dijelaskan ketika kenyataan sama atau lebih besar dari harapan maka wisatawan akan merasa puas, ketika kenyataan kurang dari harapan maka wisatawan akan merasa tidak mendapatkan kepuasan (Chaundary, 2000). Kepuasan wisatawan pada destinasi wisata Kota Sawahlunto dapat dilihat dari wisatawan menikmati kunjungan ke destinasi wisata kemudian puas dengan keputusan berkunjung, selain itu wisatawan mendapatkan perasaan yang menyenangkan ketika berkunjung, selanjutnya wisatawan juga puas dengan pengalaman berkunjung dan menyatakan bahwa pilihan berkunjung ke destinasi wisata Kota Sawahlunto merupakan pilihan yang tepat serta merasakan bahwa kunjungan ke destinasi tersebut lebih baik dari perkiraan wisatawan sehingga satisfaction wisatawan tersebut akan mempengaruhi behavioral intentions wisatawan pada destinasi wisata Kota Sawahlunto.

Kepuasan wisatawan merupakan sesuatu yang sangat penting dalam pemberian atas layanan produk dan jasa sebuah tempat wisata, kepuasan tersebut dapat dipergunakan untuk merencanakan pemasaran, karena kepuasan dapat dijadikan alat ukur untuk evaluasi dari kinerja produk pariwisata yang diberikan (Sofi et al, 2014). Hal ini dikarenakan ketidakpuasan para pengunjung destinasi wisata terhadap hal yang kecil juga dapat mempengaruhi keinginan wisatawan untuk berkunjung atau datang kembali serta merekomendasikan tempat wisata kepada orang lain atau kerabatnya (Pizman dkk, 2009). Hal ini mengindikasikan bahwa kepuasan wisatawan berpengaruh terhadap niat berkunjung kembali wisatawan.

Hasil penelitian ini sejalan dengan hasil penelitian Tsaur, Chiu dan Wang (2007) yang menemukan kepuasan juga memiliki pengaruh yang signifikan dan positif terhadap niat perilaku. Begitu juga dengan hasil penelitian Sulanjari dan Roostika (2018) yang menemukan kepuasan wisatawan berpengaruh positif terhadap niat perilaku serta hasil penelitian Ali, dkk (2015) juga menemukan satisfaction berpengaruh positif terhadap behavioural intentions.

\section{Kesimpulan dan Saran}

\subsection{Kesimpulan}

Dari hasil penelitian yang telah dilakukan, maka didapatkan hasil mengenai penilaian wisatawan pada destinasi atau tempat wisata di Kota sawahlunto bahwa education berpengaruh positif signifikan terhadap emotion wisatawan. Entertainment tidak berpengaruh positif signifikan terhadap emotion wisatawan Escapism berpengaruh positif signifikan terhadap emotion wisatawan. Selanjutnya esthetics berpengaruh positif signifikan terhadap emotion wisatawan.

Selanjutnya Emotion berpengaruh positif signifikan terhadap satisfaction wisatawan, kemudian emotion berpengaruh positif signifikan terhadap behavioral intentions wisatawan serta satisfaction berpengaruh positif signifikan terhadap behavioral intentions wisatawan.

\subsection{Saran}

Dari kesimpulan yang diperoleh tersebut, maka hal yang dapat disarankan untuk pengembangan destinasi atau tempat wisata di Kota Sawahlunto adalah sebagai berikut :

1. Pemerintah Kota Sawahlunto bersama Dinas Pariwisata Kota Sawahlunto disarankan untuk meningkatkan publikasi secara luas objek-objek wisata sehingga hal tersebut dapat mempengaruhi experience economy (pengalaman ekonomi) yang terdiri dari educational, entertainment, escapism dan esthetics serta emotion dan behavioral intentions wisatawan terkait rangsangan pengalaman ekonomi.

2. Pemerintah Kota Sawahlunto bersama Dinas Pariwisata Kota Sawahlunto perlu untuk memperhatikan faktor eksternal yang dapat mempengaruhi experience economy, emotion dan behavioral intentions wisatawan seperti memperbaiki aksesibilitas, memperbaiki kualitas destinasi wisata baik dari sarana maupun fasilitas wisata juga, dan infrastruktur pada objek wisata Sawahlunto.

3. Pemerintah Kota Sawahlunto bersama Dinas Pariwisata Kota Sawahlunto disarankan untuk menyediakan pusat layanan informasi tentang sejarah dan lokasi destinasi wisata yang lengkap yang dapat diakses oleh wisatawan dimanapun berada.

4. Keterbatasan penelitian ini adalah wisatawan yang berkunjung ke destinasi wisata Sawahlunto adalah wisatawan nusantara dan mancanegara, namun yang diteliti hanya wisatawan nusantara.

5. Penelitian selanjutnya diharapkan dapat dilakukan khusus kepada wisatawan mancanegara sehingga bisa diketahui lebih lanjut pengaruh experience economy (pengalaman ekonomi) yang terdiri dari educational, entertainment, escapism dan esthetics terhadap emotion wisatawan sekaligus dampaknya pada 
kepuasan (satisfaction) wisatawan dan behavioral inetention wisatawan mancanegara, sehingga dapat dijadikan perbandingan untuk merencanakan strategi pemasaran yang lebih tepat untuk menarik wisatawan mancanegara.

6. Penelitian selanjutnya juga dapat mengembangkan model penelitian dengan mempertimbangkan untuk menambah variabel penelitian lain yang dapat mempengaruhi perilaku wisatawan dalam mengunjungi sebuah destinasi wisata.

\section{Referensi}

Ali, Faizan, Kisang Ryu \& Kashif Hussain. 2015. Influence of Experiences on Memories, Satisfaction and Behavioral Intentions: A Study of Creative Tourism, Journal of Travel \& Tourism Marketing, To link to this article: http://dx.doi.org/10.1080/10548408.2015.1038418

Baker, D. A., \& Crompton, J. L. 2000. Quality, satisfaction, and behaviour intentions. Annals of Tourism Research, 27(3) 785-804

Christianto, Ayline Kusuma Dewi. 2013. Aplikasi Dimensi Experience Economy (Education, Esthetics, Entertainment, Escapism) Dalam Industri Restoran : Studi Kasus Pada Restoran Comedy Kopi Surabaya. Jurnal Manajemen Perhotelan, Universitas Kristen Petra, Surabaya, Indonesia

Chaundary, M. 2000. India's Image as a Tourists Destination - A Perspective of Foreign Tourists . Tourism Management , 293-297.

Das, D \& Sharma. S.K. 2005. Perspective of Foreign Tourists with Reference to a Tourist Destination: A Case Study. International Conference on Service Management (pp. 112-119). New Delhi: IIMB.

Farber, M.E. \& Hall, T.E. 2007. Emotion and environment: Visitor's extraordinary experiences along the Dalton highway in Alaska. Journal of Leisure Research, 39 (2), 248-270
Ghozali, Imam 2014. Structural Equation Modeling Metode Alternatif Dengan Partial Least Square (PLS) Dilengkapi Software Smartpls 3.00 Xistat 2014 dan WarpPLS 4.0. Edisi 4. Semarang : Badan Penerbit Universitas Diponegoro Semarang

Ismayanti. 2010. Pengantar pariwisata. Jakarata : PT Gramedia Widiasarana Indonesia.

Kotler, Philip, dan Kevin Lane Keller. 2009. Manajemen Pemasaran, Edisi 13, Jilid 1 \& 2. Jakarta : Erlangga

Liang, J. C. L. H., Lin, J. C., \& Liang, H. 2012. The influence of service environments on customer emotion and service outcomes. International Journal of service Marketing, Vo. 10 Iss 6 pp. 45-61.

Lovelock, C. H., Patterson, P., Wirtz, J. 2015. Services Marketing: An Asia-Pacific and Australian Perspective. 6th ed. Australia: Pearson Australia Group Pty Ltd.

Loureiro, Sandra Maria Correia. 2014. The role of the rural tourism experience economy in place attachmentand behavioral intentions. International Journal of Hospitality Management 40 (2014) 1-9

Mei, X.Y. 2014. Boring and expensive: The challenge of developing experience-based tourism in the Inland region, Norway. Tourism Management Perspectives, Vol.12, pp. 71-80

Manthiou, Aikaterini, Seonjeong Lee dan Liang (Rebecca) Tang Ph.D. 2011. Measuring the Experience Economy and the Visitors Behavioral Consequences: An Empirical Study on Veishea Event https://scholarworks.umass.edu/gradconf_hospitality/ 2011/Presentation/107/

Pine, B. J. II, Gilmore, J. H. 1998. Welcome to the Experience Economy. Harvard Business Review. p.97-105. 
Pizman, A., Neuman, Y., Reichel, F. (2009). Tourists Satisfaction, Uses and Misuses. Annals of Tourism Research, 96-107.

Radder, Laetitia dan Han, Xiliang. 2015. An Examination Of The Museum Experience Based On Pine And Gilmore's Experience Economy Realms. The Journal of Applied Business Research March/April 2015 Volume 31, Number 2

Sarwono, Jonathan. 2012. Metode Riset Skripsi Pendekatan Kuantatitif (Menggunakan Prosedur SPSS) Tuntutan Praktis Dalam Menyusun Skripsi. Jakarta : Elex Media Komputindo

Shen, H., Fan, S., Zhan, J., \& Zhao, J. 2014. A Study of the Perceived Value and Behavioral Intentions of Chinese Marine Cruise Tourists. Tourism, Leisure and Global Change, 1(April), 96-117.

Siwi, Bety Raga. 2018. Analisis Pengaruh Customer Emotion Terhadap Behavioral Intentions Dengan Mediasi Servicesatisfaction Pada Jasa Umrah Arminareka Perdana Di Karanganyar. Skripsi. Jurusan Manajemen Bisnis Syariah Fakultas Ekonomi Dan Bisnis Islam Institut Agama Islam Negeri Surakarta

Sofi, Maraj Rehmanet al. 2014. "Service Quality Variables and Tourist Satisfaction at Destination Level - A Study of J\&K Tourism". International Journal of Applied Research and Studies. vol 3 Pp1-9.

Spears, N., \& Singh, S. 2004. Measuring Attitudes Toward The Brand And Purchase Intentions. Journal of Current Issues And Research in Advertising, 53-66

Sugiyono. 2014. Metode Penelitian Bisnis. Bandung : Alfabeta

Sulanjari1, Bintang dan Roostika, Ratna. 2018. Analisis Pengaruh Kesadaran Harga, Persepsi Nilai, dan Kepuasan Wisatawan terhadap Niat Perilaku
Berbelanja di Malioboro. Jurnal Universitas Islam Indonesia

Tsaur, Sheng-Hshiung, Yi-Ti Chiu \& Chih-Hung Wang. 2007. The Visitors Behavioral Consequences of Experiential Marketing, Journal of Travel \& Tourism Marketing, 21:1, 47-64 To link to this article: http://dx.doi.org/10.1300/J073v21n01_04

Tjiptono, Fandy. 2014. Pemasaran Jasa. Yogyakarta : Andi Offset

Wijanarka, Yuda. 2014. Pengaruh Emotional branding dan Experiential marketing Terhadap Loyalitas Merek Eiger Adventure Melalui Brand trust dan Kepuasan Pelanggan Sebagai Variabel Intervening (Studi Kasus Pada Eiger Adventure Store Semarang). Diponegoro Journal Of Social And Political Of Science Tahun 2014, Hal. 1-12 http://ejournal-s1.undip.ac.id/index.php/

Wu, H., Ai, C., Yang, L., Li, T., \& Ai, C. 2015. A Study of Revisit Intentions, Customer Satisfaction , Corporate Image, Emotions and Service Quality in the Hot Spring Industry A Study of Revisit Intentions , Customer Satisfaction, Corporate Image, Emotions and Service Quality in the Hot Spring Industry. Journal Of China Tourism Research, 11: 371-401,ISSN: 1938 - 8160.

Tribuntravel.com 14 Tempat Wisata Populer di Sawahlunto yang Menarik untuk Dikunjungi, Minggu

Juli

2019,

(https://travel.tribunnews.com/2019/07/07/14-tempat -wisata-populer-di-sawahlunto-yang-menarik-untukdikunjungi), diakses Juli 2019.

Kompas.com Sawahlunto, dari Kota Mati Jadi Kota yang Diakui, 6 Agustus 2019 (https://foto.kompas.com/photo/read/2019/8/6/ 1565061786633/1/Sawahlunto-dari-Kota-Mati-JadiKota-yang-Diakui) diakses November 2019 